\title{
Article
}

\section{Libelling Oscar WHide: The case of Regina vs. John Sholto Douglas}

\author{
Archer, Dawn Elizabeth \\ Available at https://clok.uclan.ac.uk/4974/ \\ Archer, Dawn Elizabeth (2011) Libelling Oscar Wilde: The case of Regina vs. \\ John Sholto Douglas. Journal of Politeness Research, 7 (1). pp. 73-99. ISSN \\ 1613-4877
}

It is advisable to refer to the publisher's version if you intend to cite from the work. http://dx.doi.org/10.1515/jplr.2011.004

For more information about UCLan's research in this area go to

http://www.uclan.ac.uk/researchgroups/ and search for <name of research Group>.

For information about Research generally at UCLan please go to http://www.uclan.ac.uk/research/

All outputs in CLoK are protected by Intellectual Property Rights law, including Copyright law. Copyright, IPR and Moral Rights for the works on this site are retained by the individual authors and/or other copyright owners. Terms and conditions for use of this material are defined in the policies page.

\section{CLoK}

Central Lancashire online Knowledge www.clok.uclan.ac.uk

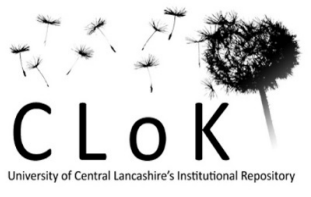




\section{Libelling Oscar Wilde: The case of Regina vs. John Sholto Douglas}

DAWN ARCHER

\section{Abstract}

This paper explores the 1895 libel trial between Oscar Wilde (literary personality) and the Marquis of Queensbury (father of Wilde's close friend). Focussing on the lead defence counsel's cross-examination of Wilde (plaintiff), I demonstrate that Carson's FTAs are "aggressive" and, in some cases, "deliberately" so (cf. Bousfield 2008: 72). However, as they do not breach the rules of the courtroom or involve an overt "intent to harm" (Goffman 1967: 14), I argue that they do not constitute impoliteness. I further argue that Carson's FTAs should not be considered "incidental" in nature, given they were more planned and more anticipated than Goffman's (1967: 14) definition seems to allow, and thus suggest that Carson's FTAs be recognized as sitting somewhere between Goffman's intentional or incidental levels - thanks, in part, to their manipulation of multiple goals (Penman 1990) - in what I have labelled the ambiguous-as-to-speakerintent zone (Archer under review). I also demonstrate Carson's uselmanipulation of representational frames and reality paradigms so as to emphasize Wilde's moral "deviance". In brief, a reality paradigm equates to "the systems of beliefs [and] values ... by reference to which a person or a society comprehends the world" (Fowler 1986: 130), and representational frames, to the way $(s)$ in which interlocutors opt to "represent the character traits, ideas and opinions of and even statements made by others" (Locher and Watts 2008: 99, n9). I conclude by responding to two questions highlighted by my investigation: (1) Should we be talking about impoliteness in the courtroom (even when investigating the cross-examination phase)? and (2) To what extent can our understanding of facework be enhanced, in both a courtroom context and more generally, via a consideration of reality paradigms (and their strategic manipulation)?

Keywords: verbal aggression, multiple goals, strategic indirectness, intentionality, reality paradigms 


\section{Introduction}

Libel trials are face-threatening for both complainant and defendant for a number of reasons. They come about because a complainant feels that a "false, scandalous and malicious" statement has been made about them by the defendant, with the express purpose of portraying them in a detrimental light. The trial itself is thus about proving or disproving the alleged smear, which often (i) means a detailed and, on occasion, very embarrassing investigation as to whether the allegation can be proven in law, and (ii) leads to the public branding of the complainant or defendant (as liar, charlatan, felon, etc.). In this paper, I investigate a particularly infamous British libel trial involving the novelist, dramatist and poet, Oscar Wilde. Wilde instigated the "defamatory libel" trial against the Marquis of Queensberry (the father of Wilde's close friend, Lord Alfred Douglas) in 1895, because of a message that Queensberry had left at Wilde's club which intimated that Wilde masqueraded as a sodomite ${ }^{1}$. Wilde opted to defend his public image via the Court system but his decision was to prove costly, as Queensberry and his team, led by $\mathrm{Mr}$ Edward Carson QC, set about demonstrating that Queensberry's allegation was true. Although Wilde ultimately withdrew his complaint, the libel case set in motion a chain of events that was to see Wilde and an accomplice, Alfred Taylor, tried (twice) and convicted (once) for gross indecencies. Drawing on Wilde's libel case (a summary of which is provided in Section 2), I will seek to demonstrate that, although facework in such a context is seldom overtly impolite in Bousfield's (2008: 72) "gratuitous" sense, i.e., "unmitigated", in a context "where mitigation is required", there is ample evidence of "deliberate aggression" and/or of face-threat being "exacerbated, 'boosted', or maximized in some way to heighten the face damage inflicted" (Bousfield's second criteria for impoliteness). This is because lawyers tend to use off-record FTAs so that they can aggravate the face of the lay participants whilst staying within the confines of courtroom protocol (see Archer 2008). Such a tactic is far from a weak option, of course, as indirectness provides a means by which (i) lawyers can problematize/render ambiguous the speaker-intent of their utterances/questions so that they can claim they were not primarily seeking to cause intentional face-damage but were merely "doing their job" (Goffman 1967: 14), and (ii) interactants still have to endure a high degree of face-damage; indeed, for Wilde, the "ignominy" of having to answer to "detail after detail" (Holland 2003: $138)^{2}$ proved to be unbearable (see Section 6-8).

I explain the motivation for the use of indirectness in the courtroom generally in Section 3, and discuss Carson's use of indirectness in the Regina vs. John Sholto Douglas libel trial from Section 3.1 onwards. I 
also discuss Wilde's use of indirectness/ambiguity - and the problems this creates for him, as lead witness, because of his lack of institutional power in this context (Section 3.2). An additional aim of this paper is to show how face-threat in a courtroom context is intimately linked to not only interlocutors' expectations and representational frames (Locher and Watts 2008) but also to their sense of reality, including what is - and is not - acceptable behaviour for them personally. I discuss reality paradigms and their relationship to facework in Sections 4 and 5. Suffice it to say that reality paradigms (as I call them in Archer 2002) are the truth filters interlocutors use to interpret/make sense of their worlds. They are thus more specific to the individual than expectation frames, which effectively equate to schemas that provide us with a socially prescribed feel for the game (Bourdieu 1990). However, they tend to overlap with or feed into representational frames, that is, the way(s) in which interlocutors opt to "represent the character traits, ideas and opinions of and even statements made by others" (Locher and Watts 2008: 99, n9). As will become clear, for example, Oscar Wilde did not share the view of the majority of Victorian society that homosexuality was sinful (Section 4, 5 and 7). In addition, he did not seem to believe that truth meant factual accuracy (Section 4); for example, he lied about his age (Section $3)$. A feature of reality paradigms, expectation frames and representational frames that I will discuss in some detail, is their tendency to clash or be in opposition in a courtroom context (Section 4-7). This is not surprising given that the point of the adversarial system is to discover truth via the contention of counsel (i. e., by choosing between opposing "crime narratives"). However, as I have shown in earlier work (Archer 2002), such clashes - when extreme enough - can affect interlocutors' ability or willingness to correctly perceive the implicatures of others; hence their link with indirectness. Representational frames and reality paradigms can also be manipulated for strategic purposes; so that, for example, a person's socio-cultural deviance is emphasized (Sections 4, 5 and 7).

\section{Regina vs. Douglas: A summary}

The libel trial between Wilde and Queensberry began on April $3^{\text {rd }} 1895$ at the Old Bailey, following two preliminary proceedings before the magistrate in March. In his opening speech, former Solicitor General Sir Edward Clarke was careful to address most of the issues raised in the Plea of Justification filed by Queensberry and his team (on March $30^{\text {th }}$ ), which claimed that Wilde had attempted to "solicit and incite" young men known and unknown "to commit sodomy and other acts of gross indecency and immorality with him" and that, in addition, he had 
"joined in procuring the publication of" or had himself written and published "immoral and obscene work" which described "the relations intimacies and passions of certain persons of sodomitical and unnatural habits tastes and practices" (PRO ref. crime 4/1118). As Clarke's aim was to present "Oscar as a loving father, a devoted friend, and an accomplished writer and artist reluctantly driven to the recourse of law" (McKenna 2003: 486) because of Queensberry's unreasonable and intimidating behaviour towards him, he did "not trouble" the jury with "allegations' of "indecent practices". But he did make it known, in passing, that the opposition had a duty to provide the jury with "credible" witnesses whose evidence was "worthy" of their consideration (Holland 2003: 28). The insinuation was obvious - Clarke was concerned that any men who did come forward to give evidence against Wilde were very likely coerced or offered cash inducements, because to admit of their own free will that they were somehow involved in the murky Uranian world of London was to open themselves up to prosecution. What is surprising, then, is Clark's mention in his opening of one of Wilde's more compromising letters to Lord Alfred Douglas; the now infamous "madness of kisses" letter, which had led to two (unsuccessful) blackmail attempts $^{3}$. His tactic, at this point, seems to have been to use Wilde's larger-than-life character as an artist to their advantage, so that he might explain away certain quirks of Wilde's behaviour as nothing more than the characteristics of a unique and extremely talented literary man. For example, Clarke acknowledged that:

... the words of that letter appear extravagant to those who are in the habit of writing commercial correspondence or ... ordinary letters ... but that, [as] Mr Oscar Wilde said ... it is a sort of prose sonnet, an answer written to a piece of poetry written to Lord Alfred Douglas, a piece of poetry which is transcribed and paraphrased in the sonnet printed in ... Spirit Lamp

(Clarke's Opening Speech, Wednesday am $3^{\text {rd }}$ April 1985 [Holland 2003: 33-34])

Following Clarke's opening speech, Clarke's co-counsel (Mathews) examined Sidney Wright, the hall porter of the Albermarle Club, to confirm that a card claiming that Wilde posed as a sodomite was left for Wilde by Queensberry on February $18^{\text {th }}$, and that the card was given to Wilde February $28^{\text {th }}$ when he next visited the club. Once this was established, Clarke questioned Wilde for an hour-and-a-half and in such a way that enabled Wilde to give an "assured and impressive" performance 
(McKenna 2003: 486). Like Clarke had done in his opening, Wilde even allowed himself the odd touch of humour when recounting issues surrounding the "madness of kisses" letter. He stated, for example, that he had told one of his would-be blackmailers to "sell [his] letter for sixty pounds" for he himself had "never received so large a sum for any prose work of that very small length", adding "I am glad to find that there is someone in England who considers that a letter of mine is worth sixty pounds" (Examination of Wilde, Wednesday am $3^{\text {rd }}$ April 1895 [Holland 2003: 53]).

Carson began his one-and-a-half day cross-examination of Wilde shortly before lunch on Wednesday $3^{\text {rd }}$. Now regarded as "one of the most bruising encounters in English legal history" (McKenna 2003: 487), Holland (2003: xxix) believes that, "by giving Wilde a day and a half to defend himself and his art, Edward Carson caught him superbly off his guard", for Oscar could not resist making "[o]ne fatal witticism too many". As the verbal duel between Wilde and Carson will be my focus from this point onwards, I need only provide a brief synopsis of Carson's strategy here. Suffice it to say, Carson began with the literary part of the case. His approach was simple but effective: "He would take a damning position about the work in question and invite Oscar to agree with him" (McKenna 2003: 488) and sometimes repeatedly so. And if Oscar attempted to expound upon or qualify his answers, he would be interrupted by Carson. As such, "the most accomplished and sought-after conversationalist of his day" was prevented from performing in his usual beguiling, enchanting, charming and hypnotizing way (McKenna 2003: 488).

Having exposed Wilde as a vain "man who, if he did not directly condone the sodomitical in literature, equally would not or could not condemn it" (McKenna 2003: 488), Carson moved on to the apparent blackmailing attempts and Wilde's "intimacy" with several young men, including Edward Shelley, Alfonso Conway, Alfred Taylor, Charles Parker, Frederick Atkins, Ernest Scarfe and Sydney Mavor. However, the most damaging moment in the trial was triggered by Carson's questions regarding Walter Grainger, a servant at Lord Alfred Douglas's rooms in Oxford. Carson asked Wilde whether he had ever kissed Grainger, to which Wilde replied "Oh, no, never in my life; he was a peculiarly plain boy" (Cross-examination of Wilde, Thursday am $4^{\text {th }}$ April 1895 [Holland 2003: 207]). Carson immediately picked up on the inference that Wilde had not kissed Grainger because he - like Wilde - was male, but rather because Grainger was "ugly". Wilde tried in vain to refute Carson's interpretation, but the damage was done.

Clarke tried valiantly to repair the damage during his re-examination of Wilde, but when he knew it would be to no avail, he advised Wilde 
to withdraw from the prosecution. As reported in the Old Bailey transcript (OBP March 1895), Wilde did so "at the close of the case for the prosecution, and whilst MR. CARSON was opening the defence" (italics in the original). Specifically,

SIR EDWARD CLARKE interposed [on Wilde's behalf] and stated that he had consulted with his client, and was prepared to accept a verdict [regarding Queensberry] of NOT GUILTY, which the JURY at once pronounced, adding that they considered that the publication was justified and for the public benefit

(OBP March 1895).

Wilde - like his accuser, Queensberry - left the Old Bailey a free man. But he was arrested that evening, and charged under Section 11 of the 1885 Criminal Law Amendment Act for "committing acts of gross indecency with other male persons". As the first trial in the April of 1895 proved inconclusive in regard to some counts, Wilde faced a second trial, in the May, following which he was pronounced guilty and sentenced to "Two Years' Hard Labour" (OBP May 1895). Freed on 19 $9^{\text {th }}$ May 1897, Wilde lived for a further three years, dying of cerebral meningitis on November $30^{\text {th }} 1900$.

\section{Indirectness, ambiguity and multifunctionality}

Off-record facework strategies are employed by Anglo-American lawyers for a number of reasons. FTAs conveyed indirectly by way of an implicature represent a flout as opposed to a violation of the Gricean maxims. That is to say, they signal the speaker's desire that the target(s) look for and infer some meaning beyond or in addition to the literal one (Searle 1975) - in the case of cross-examining lawyers, often an allegation or an insinuation - whilst nevertheless allowing them to maintain plausible deniability (Leech 1983). This plausible deniability is possible because implicatures can be cancelled if/when necessary. Plausible deniability, in turn, ensures that lawyers can legitimately claim they were merely "doing their job" if/when someone asserts they have been affronted by their questions - even though the resulting "face-damage-as-by-product" seems to be somewhat more planned and more anticipated on their part than we would expect to see as part of incidental facework more generally (Goffman 1967: 14) ${ }^{4}$. For example, consider Carson's opening exchange with Wilde, during which Carson sought clarification regarding Wilde's age:

(1) CARSON: You stated at the commencement of your examination that you were thirty-nine years of age. I think you are over forty, isn't that so? 
WILDE: I don't think so. I think I am either thirty-nine or forty - forty my next birthday. If you have my certificate there that settles the matter.

CARSON: You were born, I believe, upon the $16^{\text {th }}$ of October 1854 ?

WILDE: Yes, I have no intention of posing for a younger man at all. I try to be correct in the date.

CARSON: It makes you somewhat over forty.

WILDE: Very well.

(Cross-examination of Wilde, Wednesday am $3^{\text {rd }}$ April 1895

[Holland 2003: 64])

Carson's purpose, here, was not merely to clarify Wilde's age and thus the correctness of the information Wilde had volunteered to Clarke during examination-in-chief, but to insinuate that Wilde was prepared to lie in a court of law over something which was relatively trivial: "and if Oscar was prepared to lie about small things", then he would likely "lie about bigger things" (McKenna 2003: 487) - i. e., posing as a sodomite. Hence, Carson's somewhat convoluted strategy of asking Oscar to confirm first his age and then his birth-date, followed by a Quantity-flouting but technically correct statement regarding Oscar having passed his fortieth birthday (by six months!).

For McKenna, the fact that "Oscar had been detected in vanity" was also significant, as it was "a vice unlikely to endear itself to the upstanding burghers of Clapton and Stoke Newington" (2003: 487), that is, to the majority of the men making up the jury ${ }^{5}$. This may help to explain Wilde's attempt to mitigate his "error": note, in particular, his insistence that he tried "to be correct in the date" and his acceptance that his birth certificate would "settle the matter". But this insistence may have worked against him - as a Victorian audience would have expected such a "careful" (and highly educated) man to know his birth year.

\subsection{The strategic use of indirectness, ambiguity and multifunctionality}

For obvious reasons, Carson's indirect strategy at the opening of his cross-examination was not unduly aggressive in facework terms: after all, Wilde was the complainant in this case, not the defendant. This said, Carson became more aggressive throughout that first day. Indeed, a pattern quickly emerged whereby Carson would begin with fairly innocuous questions but repeat them several times - to the point of badgering Wilde, on occasion - thereby aggravating his negative face (i. e., Wilde's "want" to speak freely and without interruption). When 
questioning Wilde about The Priest and the Acolyte, for example, Carson continually asked him whether he thought the story "immoral" and, worse, "blasphemous", even after Wilde had been forced to admit - by Carson - that he found it neither immoral nor blasphemous. One reason for this is that Wilde had claimed he "disapproved" of the book early on in his cross-examination. However, responses such as "I thought the end, the account of the death, violated every artistic canon" (Holland 2003: 70) suggested that that disapproval was occasioned by the book's literary deficiencies as opposed to any moral or religious concerns Wilde might hold. Wilde's violation of the Manner maxim (Grice 1989: 2627) prompted Carson to make it clear to Wilde that "This [wa]s not what [he had] asked", and then to reassert his original question, "Did you think it blasphemous ...?" over and over, until Wilde responded affirmatively with a simple "yes". And even then Carson was apparently unconvinced - for he made a remark which played on the word "pose":

(2) CARSON: I want to see what position you pose in.

WILDE: Now, that is not the way to talk to me - 'to pose as'. I am not posing as anything.

(Cross-examination of Wilde, Wednesday am $3^{\text {rd }}$ April 1895 [Holland 2003: 70])

Cross-examining lawyers often play on the meaning of (and/or any intertextual or legal allusion triggered by) particular words. They will also use utterances which have different possible interpretations, so that lay participants are forced to consider primary and secondary intents, or an intent which is purposefully ambiguous, and thus more difficult to process (cf. Sperber and Wilson 1986: 204). Consider the following extract, for example, which occurred shortly after Carson had pressed Wilde about the "madness of kisses" letter and the two resultant blackmail attempts:

(3) CARSON: You have told me that you wrote a great many beautiful letters; did you ever have any one of them, excepting the one that happened to be found out, turned into a sonnet?

WILDE: I would require to read a great deal of modern poetry before I could answer that. (Laughter)

CARSON: Did you ever have any letter, except the one that was found out, turned into a sonnet? 
WILDE: I don't know what you mean by 'the one that was found out'.

CARSON: The one, sir, for which you gave the money you have just been telling of.

WILDE: I gave no money for that letter.

CARSON: What?

WILDE: I gave no money for that letter.

CARSON: In reference to which you gave the money.

WILDE: I did not give money in reference to it.

CARSON: The one which you got back?

WILDE: The one which was handed back to me.

CARSON: I ask you, sir, excepting that, have you ever had a letter turned into a sonnet?

CARSON: I say I should have to look through the whole of modern poetry to answer that question.

WILDE: Can you tell me any one?

CARSON: At the present moment I cannot; I should have to go through the whole of modern poetry; I could not. discovered letter, which was ever turned into a sonnet?

WILDE: At the present moment, no - I cannot recollect any.

CARSON: Had you ever written to Lord Alfred Douglas to preserve that letter?

WILDE: No, never.

CARSON: Therefore, sir, until it was discovered, you never thought of turning it into a sonnet.

WILDE: I never turned it into a sonnet at all.

CARSON: I did not say you did.

WILDE: When the copy was sent to Beerbohm Tree, and I saw what the letter was, then I felt at once it should be translated into a poetic form.

CARSON: You thought at once it should be translated and turned into a sonnet?

WILDE: Yes.

(Cross-examination of Wilde, Wednesday pm $3^{\text {rd }}$ April 1895

[Holland 2003: 132-133])

Carson's implication, developed over a series of questions, was that Wilde had only published the letter in the Spirit Lamp to avoid any possible legal ramifications when it was found that he had written a love letter to another man. Wilde was resistant from the outset, however. Notice his humorous quip regarding having to read "a great deal of 
modern poetry" before he could answer, for example; an attempt, on Wilde's part, to avoid answering Carson's initial question all together. Notice also Wilde's claim to not understand the presupposition behind "the one that was found out", and his implication that the "sonnet" was published because it merited publication, and not because he was trying to avoid any possible accusations of improper behaviour on his part. This and other examples of verbal duelling between Wilde and Carson seem to confirm Thomas's (1995: 74) point that witnesses expect (some of the) lawyers' utterances during cross-examination to be pragmatically misleading, and that lawyers in turn will seek to construct a witness as someone who is seeking to give a misleading impression.

The notion that interlocutors can frame one another negatively is something that Locher and Watts (2008) also discuss, but in regard to a 1984 televised political interview (relating to a Miner's Strike in the UK). There, as here, the interlocutors in question - Arthur Scargill, then President of the National Union of Miners, and Fred Emery, presenter on the BBC current affairs programme, Panorama - were constrained by institutional sanctions in regard to appropriate/permissible behaviour (verbal and non-verbal); they could not openly insult one another, for example. However, Scargill and Emery could and did seek to manipulate the audience's expectations, in regard to what to expect in this admittedly competitive and conflictual mode of interaction, as a means of suggesting that the other was breaching these appropriacy norms (i. e., was being overly aggressive, and hence rude).

As will become increasingly clear, Carson - and, to a lesser extent, Wilde - also used framing strategies as a means of portraying the other negatively. Moreover, Carson's framing devices sought to manipulate societal expectations of moral appropriacy in addition to any expectations in regard to how a cooperative witness (with nothing to hide) would behave in this context. In the above extract, for example, Carson re-introduced the idea (previously made by Wilde) that he had written many "beautiful letters to Lord Alfred Douglas" aka Bosie (Holland 2003: 108), one of which Carson had opted to read aloud so that he might get Wilde to confirm that it was, in fact, "a love letter":

(4) CARSON: Dearest of all Boys, Your letter was delightful - red and yellow wine to me: but I am sad and out of sorts. Bosie, you must not make scenes with me: they kill me. They wreck the loveliness of life. I cannot see you, so Greek and gracious, distorted by passion - I cannot listen to your curved lips saying hideous things to me. Don't do it. You break my heart. ... I must see you 
soon. You are the divine thing I want - the thing of grace and genius ... why are you not here, my dear, wonderful boy? ... Ever your own Oscar

(Cross-examination of Wilde, Wednesday pm $3^{\text {rd }}$ April 1895

[Holland 2003: 108])

But Wilde preferred the description "a letter expressive of love", his play on words being an attempt to invoke a myriad of platonic relationships, of course. Carson was not satisfied:

(5) CARSON Is it the kind of letter that one man writes towards another man?

WILDE: It is the kind of letter that I have written to Lord Alfred Douglas. What other men write to other men I know nothing about, nor do I care.

CARSON: Have you got the letter from Lord Alfred Douglas to which that was an answer?

WILDE: I don't think so. I don't know what letter it was at all (Cross-examination of Wilde, Wednesday pm $3^{\text {rd }}$ April 1895

[p.110])

Wilde did not help himself by stating that he did not "care" whether his actions were representative of how Victorian men usually write to individuals of the same sex, not least because it allowed Carson to continue constructing him as a resistant witness, who used evading strategies because he did not want to have to confirm and/or to provide information which might ultimately prove to be self-damaging. For example, Carson immediately cast doubt on Wilde's claim that he didn't remember this particular letter - in spite of its beauty:

(6) CARSON: You don't remember the letter, but you describe it as 'delightful red and yellow wine' to you?

And he implied that Wilde was the sort who was prepared to "buy" people's silence:

(7) CARSON: What would you pay for that beautiful letter? ... How much would you give now, if you could get a copy?

WILDE: I don't know. Why do you taunt me with such questions? 
CARSON: You really don't know? Was this letter a beautiful letter, this one of yours?

WILDE: Yes. I think it contains reproaches. It isn't like the other - a prose poem. It is a letter expressive of my great devotion to Lord Alfred Douglas. I can say no more.

(Cross-examination of Wilde, Wednesday pm $3^{\text {rd }}$ April 1895

[Holland 2003: 111])

Wilde's complaint to Carson, "Why do you taunt me with such questions?", and Carson's response, "You really don't know?" are especially worthy of comment. The complaint seemed to serve two purposes: it indicated, publicly, that Carson's actions were causing Wilde to experience face-damage, and hence allowed Wilde to frame Carson's behaviour (and, by implication, Carson himself) in a negative light, regardless of whether Carson was technically breaching any norms at this juncture (Locher and Watts 2008: 79). Carson's rhetorical question, in turn, allowed him to counter with a frame of his own: that Wilde was consciously hiding the truth, and doing everything in his power to keep the truth hidden.

\subsection{Wilde's use of indirectness, ambiguity and multifunctionality}

Wilde was an atypical witness in many ways; not least because he countered Carson's indirectness, ambiguity and multifunctionality with indirectness and ambiguity of his own. Note, for example, Wilde's rebuke of Carson - "that is not the way to talk to me" (Holland 2003: 70) - which seems to preface both Wilde's correction of Carson's English (correcting Carson's English is something Wilde did intermittently throughout the libel trial) and also his assertion that he did not "pose" as anything: an assertion which suggests Wilde had interpreted Carson's posing comment as an intertextual reference alluding to the claim which had sparked this libel case; that Wilde posed as a sodomite (see Section 3.1).

In facework terms, Wilde's correction of Carson's English would have aggravated the lawyer's "quality" face (Spencer-Oatey 2002), i.e., his desire to be evaluated positively in regard to his (personal) abilities, in addition to his "social identity face" as lawyer (Spencer-Oatey 2002); after all, it was Carson who held institutional power in this context, not Wilde. Wilde's reprimand ("that is not the way to talk to me") might also be seen as a claim to "equity rights" on Wilde's part, that is to say, to not be unduly imposed upon, taken advantage of or exploited by Carson (Spencer-Oatey 2002), given that Wilde was the complainant/ 
prosecutor and not the accused. But in libel cases it is the prosecutor who often finds himself having to defend his (alleged) behaviour, especially during the cross-examination phase, not least because the accused must justify their libel (i. e., "prove" their allegations "true" in law). As such, although Carson seemed to take this particular reprimand in good spirits ("I beg your pardon"), he was quick to remind Wilde that he had "a great deal to ask him", and to request that he therefore simply "answer "yes' or "no" from this point onwards. Carson also added a reproof of his own - "You are a gentleman who understands a question perfectly" ${ }^{-}$- before asking Wilde once again:

(8) CARSON: [...] Did you or did you not consider that story of 'The Priest and the Acolyte' a blasphemous production?

WILDE: I did not consider that story a blasphemous production.

CARSON: Very well; I am satisfied with that.

WILDE: I thought it disgusting

(Cross-examination of Wilde, Wednesday am $3^{\text {rd }}$ April 1895

[Holland 2003: 70])

Wilde's unnecessary comment - "I thought it disgusting" - at the point at which Carson signalled his eventual satisfaction (having repeatedly asked Wilde about the "blasphemous" content of The Priest and the Acolyte) suggests that Wilde was too used to having the last word. It was a character trait which had served him particularly well in his literary career, of course, but it was to prove disastrous for him in this particular context.

\section{Truth, reality and the courtroom}

Victims of libel enter the courtroom knowing that their behaviour/lifestyle/life choices will be put under the microscope. As has become evident, they also tend to find that they have to convince the jury that their account - in regard to what happened and/or what they believe - and not the defendant's is the "true" one (this is in spite of the fact that, legally, the burden of proof falls on the defendant in libel trials). At the same time, the defence counsel will tend to operate from within an unwilling paradigm: the belief that $\mathrm{X}$ is and/or has done what $\mathrm{Y}$ claims, but is unwilling to tell the truth (cf. Harris 1984: 18; Archer 2002: 20). Carson definitely held fast to his belief that Queensberry's allegations against Wilde were true, and part of his strategy in proving this was to 
make evident Wilde's "peculiar" view of literature, "truth" and life in general when compared with those of the average Victorian man.

In my introduction to this paper, I defined reality paradigms as "the truth filters" which "interlocutors use to interpret/make sense of their worlds". Length constraints prevent a very detailed discussion here. Suffice it to say, my concept of a reality paradigm is very similar to Fowler's (1986) notions of ideological "point of view" and "mind style". Fowler defined the former as "the systems of beliefs, values, and categories by reference to which a person or a society comprehends the world" (1986: 130), and made it clear from the outset that such a notion did not merely apply to literature; indeed, he analyzed the different ideological viewpoints of several newspapers in his groundbreaking work, Linguistic Criticism. In contrast, "mind style" is a literary concept, as his definition highlights: "the worldview of an author, or a narrator, or a character, constituted by the ideational structure of the text" (1986: 150). Notice the absence of a societal worldview here, and the resultant focus on individual worldviews. Moreover, mind style tends to be used to depict worldviews that are odd in some way, and thus marked (when compared to the societal "norm"). I believe that mind style as well as point of view, both of which are captured by my notion of reality paradigm, can help us to understand what might lay behind certain framing devices - such as Carson's attempts to make evident the oddness of Wilde's belief system to the jury (when contrasted with their own "common-sense", socially-legitimated worldview). Carson was able to demonstrate to the jury that Wilde didn't believe in "truth" as a fixed, absolute entity, for example: when asked about his Phrases and Philosophies for the Use of the Young, Wilde admitted that much of what he wrote was "not true ... in the actual sense of correspondence to actual facts of life". This was not problematic for Wilde, as the purpose of the Phrases was to "stimulate thought in people of any age". But Carson went on to link the notion of truth with (im)morality, by asking Wilde whether "anything that stimulate[d] thought" was acceptable, "whether moral or immoral?". Wilde's response was to counter Carson's presupposition that thought could be moral or immoral. Carson read aloud several more of Wilde's Phrases, for the benefit of the jury, including one which claimed that "a truth ceases to be true when more than one person believes in it". When asked whether he thought that this was "right", Wilde responded that he did, adding "the same truth can never be apprehended by two minds" as "to each mind there is its own truth" (Holland 2003: 76). Carson then asked Wilde whether one person could influence another adversely. Wilde did not think so: 
(9) WILDE: I don't think there is any influence, good or bad, from one person over another. I don't think so.

CARSON: A man never corrupts a youth?

WILDE: I think not.

CARSON: Nothing he could do would corrupt him.

WILDE: Oh, if you are talking of separate ages it is nonsense.

CARSON: No sir, I am talking common sense.

WILDE: Do not talk like that ... personally, as a mere philosophical point, I don't think - I am talking of grown human beings - that one person influences another. I don't think so. I don't believe it.

CARSON: You don't think that one man could exercise any influence over another? I may take that as a general statement?

WILDE: As a general statement, yes. I think influence is not a power that can be exercised at will by one person over another: I think it is quite impossible psychologically.

CARSON: You don't think that flattering a young man, telling him of his beauty, making love to him in fact, would be likely to corrupt him?

WILDE: No.

(Cross-examination of Wilde, Wednesday pm $3^{\text {rd }}$ April 1895

[Holland 2003: 102])

Notice how Wilde's reference to "a person" and "another" became "youth" and "young man" when repeated back to Wilde for clarification. Similarly, "influence" became "corrupts"; a much more pejorative term. Note, also, Carson's suggestion that a young man might be corrupted by "telling him of his beauty, [and] making love to him"; Wilde's counter that flattery and making love were not acts which might corrupt young men, and, finally, Carson's use of the term "common sense", which effectively established his perspective as the societal norm. At issue, of course was the (im)morality of homosexual practices. For Wilde, such practices were "misunderstood"; as he made clear in his April trial, there was "nothing unnatural" about the "Love that dare not speak its name". In fact, it was "beautiful ... fine ... the noblest form of affection" (Cross-examination of Wilde by Charles Gill, April 1895, cited in McKenna 2003: 527). A relationship "between an elder and a younger man, when the elder man has intellect, and the younger man has all the joy, hope and glamour of life before him" was also "beautiful" but equally misunderstood by Victorian society, according to Wilde (2003: 527). Such a sentiment was perceptible, albeit indirectly, in Wilde's "if you are 
talking of separate ages it is nonsense" comment (see above). However, Carson was careful to restrict Wilde's verbal action-environment so that he could not make this point in the eloquent way he managed to in his trial for gross indecency. Wilde, in turn, was careful not to implicate himself by admitting directly that he engaged in such practices; for to do so at this stage would have proven Queensberry's libel to be true. Hence, Carson had to resort to other tactics to glean the "truth" from Wilde, including putting him under so much pressure that the truth emerged despite his best efforts to conceal it (Lakoff 1990: 90).

\section{5. "The love that dare not speak its name"}

Carson's most damaging questioning sequences were reserved for Wilde's relationship with the young men that he had met through Alfred Taylor. When Carson first asked questions in connection with Taylor and these young men, he had been careful to make much of Taylor's "peculiar" living quarters (Holland 2003: 154-156). Indeed, he asked Wilde whether his rooms were overly "luxurious" given their location ("the upper part of College Street"), whether the curtains were always kept drawn, and whether the rooms were "always highly perfumed". By so doing, he managed to paint a picture, for the jury, of a very effeminate abode, which sounded more like a brothel than a home. Carson also asked Wilde about Taylor's proclivity for "lady's costumes" (2003: 158). Carson was trying to shock the jury, of course, and he was not finished. He went on to ask Wilde whether he knew that Taylor and one of his associates, Parker, had been "arrested together in a raid that was made on a house in Fitzroy Square" (2003: 162) and that, "at the time they were arrested they were in company with several men in women's clothes" (2003: 180). Wilde confirmed that he did and later admitted that, although he "was very much distressed" (2003: 180), it made no difference to him in regard to whether he should stay "friends" with them. Carson also asked Wilde to confirm that Taylor was "notorious for introducing young men to older men" (2003: 163). Wilde's response was to assert, quite categorically, "No, I never heard that in my life". But for some reason Wilde immediately volunteered information that, for Carson, was tantamount to an admission; namely, that Taylor had "introduced young men to" Wilde and that, in fact, Wilde had "constantly met young men" because he liked, indeed, delighted in their "society" (2003: 163-164). Carson went on to query Wilde doggedly in regard to both his (i) motivation for spending so much time in the company of young men nearly half his age, given they were not literaryminded and were from poor backgrounds (for Victorian society was very 
class-aware), and (ii) his willingness to shower them with gifts, including money.

As the following extract highlights, questions regarding Wilde's benevolence towards the young men were normally followed (more or less immediately) by questions which sought to establish whether any "intimacy" had taken place between them:

(10) CARSON: Did you give ... [the money] to him all at once?

WILDE: Yes, all at once.

CARSON: Was he in your bedroom at any time?

WILDE: Not that I remember.

CARSON: What?

WILDE: $\quad$ Not that I remember. My bedroom was off my sitting room. If you ask whether, when I was putting my coat on in my bedroom he came in, I dare say he did. I don't see why he should not, but he was never in my bedroom in the sense that you imply.

CARSON: Do you recollect as a fact his being in your bedroom?

WILDE: No, I don't recollect as a fact that he was in my bedroom. The bedroom was off my sitting room. I don't see why he should not have done it. I am not fencing with the question.

CARSON: No. Did improprieties take place between you?

WILDE: None.

CARSON: How long used he to stay on each of these occasions when he came to tea?

WILDE: An hour I think - yes.

CARSON: What was he doing all that time?

WILDE: Do you ask me what a young man does when he comes to have tea with me? He has his tea, he smokes cigarettes and I hope he enjoys it.

CARSON: Really? What I would like to ask you is this: what was there in common between you and this young man of this class?

WILDE: Well, I will tell you, Mr Carson, I delight in the society of people much younger than myself. I like those who may be called idle and careless. I recognize no social distinctions at all of any kind and to me youth - the mere fact of youth - is so wonderful that I would sooner talk to a young man half an hour than even be, well, cross-examined in court. (Laughter.) 
CARSON: Then, do I understand that even a young boy that you would pick up in the street would be a pleasing companion to you?

WILDE: Oh, I would talk to a street Arab if he talked to me, with pleasure.

CARSON: And take him into your room?

WILDE: If he interested me.

(Cross-examination of Wilde, Wednesday am $3^{\text {rd }}$ April 1895

[Holland 2003: 174-175])

The insinuation was clear: Wilde was prepared to pay for the sexual services of young men. Wilde seemed to be aware of Carson's line of attack (see, for example, his remark that "he was never in my bedroom in the sense that you imply" and also his assertion that he was not prepared to "fence" with Carson). Even so, he could not resist making the odd clever remark: notice, in particular, Wilde's quip that he "would sooner talk to a young man [for] half an hour than ... be ... crossexamined in court". Although it provoked laughter at the time, Wilde's tactic was an extremely dangerous one, not least because it allowed Carson to establish that Wilde was not averse to "picking up" young street boys. This could mean only one thing to a Victorian audience: prostitution (McKenna 2003: 498). Note, in addition, Wilde's admission that he "recognise[d] no social distinctions at all of any kind", which, according to McKenna (2003: 497), would have "struck the jury" as "something akin to anarchism". Cumulatively, these revelations served to confirm that Wilde was a very dangerous man when judged against the norms established by Victorian society (cf. Fowler 1986).

\section{Libel trials: A site of impoliteness?}

Carson's questions regarding each of the "young men" named in Queensberry's Plea of Justification included: "Did any indecencies take place between you?", "Did you ever open his trousers?", "Did you put your hands inside his trousers?", "Did you put your hand on his person?", "Did you ever put your own person between his legs?", "Did you ever embrace him?", "Did you kiss him?", "Sleep in the same bed with him all night? ... Each of you having taken off all your clothes ...?”, “... had you any familiarities with him of any kind?" (Holland 2003: 118, $138,146,204)$. Wilde found the "ignominy" of these yes-no questions particularly difficult to deal with - to the extent that, at one point, he beseeched the judge to come to his aid: 
(11) WILDE: My lord, is it not sufficient for me to give an entire denial without being exposed to the ignominy of detail after detail of an imaginary thing going on? Let it be sufficient for me to give my entire denial to that having occurred. It never did occur. Why should I be exposed before the whole court by entering into this kind of thing which cannot possibly be borne.

CARSON: Unfortunately we have -

WILDE: I appeal to his lordship.

JUDGE: Do you require further details on this point?

CARSON: No, my lord.

(Cross-examination of Wilde, Thursday am $3^{\text {rd }}$ April 1895

[Holland 2003: 138])

Given what we now know of Wilde's lifestyle, i.e., that the allegations made by Queensberry against Wilde were not "imaginary" but based on solid evidence, we can safely state that Wilde's petition to the judge equated to a violation of the first component of the Quality maxim ("do not say what you believe to be false") and, at the same time, flouted the second component of the Quantity maxim ("do not make your contribution more informative than is required"). Notice, also, Wilde's choice of speech acts: rhetorical questions and a Let-imperative. The imperative, "Let it be sufficient for me to give my entire denial ...", is particularly interesting, as Wilde obviously did not want to be exposed for what he was - someone who wasn't merely posing as a homosexual but actually engaged in homosexual practices with prostitutes - as homosexuality was a crime, punishable by imprisonment. The court accepting his "entire denial" would hence serve his best interest. This is not to say that Carson's "detail after detail" was not ignominious for Wilde. Indeed, this petition and a complaint to Carson that Wilde made, which I explore in Section 7, provide us with clear evidence that Wilde experienced a high degree of face-damage during this particular part of the libel trial. Yet, in the main, Carson appeared to operate within the "norms of appropriateness" (Locher and Watts 2008) for this setting - especially given the sensitive nature of the allegations. In fact, at the end of the libel trial, the judge (Mr Justice Collins) sent Carson a note congratulating him "on having escaped most of the filth" (cited in Holland 2003).

Carson's indirectness/intentional ambiguity helps to explain why he was able to avoid any legal censure from the judge whilst nevertheless engaging in deliberate aggression toward Wilde (cf. Bousfield 2008). Rather than labelling this as (intentional) impoliteness or incidental facework, however, I would suggest that the bulk of Carson's facework falls 
somewhere between Goffman's (1967) incidental and intentional levels, in a facework zone I've labelled "indeterminate-as-to-speaker-intent" (Archer under review). My decision to use "zone" is deliberate: it is meant to suggest an intentionality scale, which is delineated by a speaker's (S's) orientation/adherence to the expectations of their occupational, social and/or institutional role or to more affective considerations (cf. Ide's 1989 definition of affect as a variable that reflects the psychological attitude of S). The affective versus task-oriented delineation needs to be used intelligently/sensitively, of course, as participants - lawyers, in particular - can perform emotions that they, themselves, are not experiencing personally: and will often do so, if it proves strategically expedient.

\section{Stings, insults and insolent questions}

The rules of the courtroom help to ensure that lawyers (past and present) were/are more likely to use emotion or the semblance of emotion (such as "shocked", "indignant", "surprised", "angry", etc.) strategically rather than using, say, "haphazard impoliteness" (Culpeper's 2005 term for displays of emotion that represent emotional outbursts/loss of control on the speaker's part). I've already touched upon one such example: Carson's use of shock tactics when describing Taylor and his lifestyle (Section 5). Emotions are also in play in the following example, involving Carson's questioning of Wilde in regard to Grainger (the servant attached to Lord Alfred Douglas's rooms at Oxford). However, the primary aim of Carson's strategy here seems to have been to provoke an emotional outburst:

(12) CARSON: Were you on familiar terms with Grainger?

WILDE: What do you mean by 'familiar terms'?

CARSON: I mean to say did you have him to dine with you or anything of that kind?

WILDE: Never in my life.

CARSON: What?

WILDE: No! It is really trying to ask me such a question. No, of course not. He waited on me at table; he did not dine with me.

CARSON: I thought he might have sat down. You drew no distinction.

WILDE: Do you think that in the case of Lord Alfred Douglas and Lord Encombe's rooms that would have happened with the servant? 
CARSON: You told me yourself -

WILDE: It is a different thing - if it is people's duty to serve, it is their duty to serve; if it is their pleasure to dine, it is their pleasure to dine and their privilege.

CARSON: You say not?

WILDE: Certainly not.

CARSON Did you ever kiss him?

WILDE: Oh, no, never in my life; he was a peculiarly plain boy.

CARSON: He was what?

WILDE: I said I thought him unfortunately - his appearance was so very unfortunately - very ugly - I mean I pitied him for it.

CARSON: Very ugly?

WILDE: Yes.

CARSON: Do you say that in support of your statement that you never kissed him?

WILDE: No, I don't; it is like asking me if I kissed a doorpost; it is childish.

CARSON: Didn't you give me the reason that you never kissed him that he was too ugly?

WILDE: (warmly): No.

CARSON: Why did you mention his ugliness.

WILDE: No, I said the question seemed to me like - your asking me whether I ever had him to dinner, and then whether I had kissed him - seemed to me an intentional insult on your part, which I have been going through the whole of this morning.

CARSON: Because he was ugly?

WILDE: No.

CARSON: Why did you mention the ugliness? I have to ask these questions.

WILDE: I say it is ridiculous to imagine that any such thing could possibly have occurred under any circumstances.

CARSON: Why did you mention his ugliness?

WILDE: For that reason. If you asked me if I had ever kissed a doorpost, I should say, 'No! Ridiculous! I shouldn't like to kiss a doorpost.' Am I to be cross-examined on why I shouldn't like to kiss a doorpost? The questions are grotesque.

CARSON: Why did you mention the boy's ugliness?

WILDE: I mentioned it perhaps because you stung me by an insolent question. 
CARSON: Because I stung you by an insolent question?

WILDE: Yes, you stung me by an insolent question; you make me irritable.

CARSON: Did you say the boy was ugly, because I stung you by an insolent question?

WILDE: Pardon me, you sting me, insult me and try to unnerve me in every way. At times one says things flippantly when one should speak more seriously, I admit that, I admit it - I cannot help it. That is what you are doing to me.

CARSON: You said it flippantly? You mentioned his ugliness flippantly; that is what you wish to convey now?

WILDE: Oh, don't say what I wish to convey. I have given you my answer.

CARSON: Is that it, that that was a flippant answer?

WILDE: Oh, it was a flippant answer, yes; I will say it was certainly a flippant answer.

CARSON: Did ever any indecencies take place between you and Grainger?

WILDE: No, sir, none, none at all.

(Cross-examination of Wilde, Thursday am $3^{\text {rd }}$ April 1895 [Holland 2003: 207-209])

Notice that Carson's initial "dining" questions alluded to Wilde's claim that he drew no social distinctions of any kind (see Section 5), and they provoked a response of irritation from Wilde: "It is really trying to ask me such a question. No, of course not". Carson immediately moved on to query Wilde as to whether his "familiarity" in Grainger's case therefore extended to him kissing "the boy". Wilde was apparently caught off guard by this; he suggested - quite freely - that he did not kiss Grainger as he found him to be "peculiarly plain" and "very ugly". Carson pursued this with Wilde, by asking him to confirm that he had meant to imply Grainger was "very ugly ... in support of [his] statement that [he] never kissed him". By this point, Wilde was all too aware of his gaffe, and tried to ridicule the "childish" suggestion - by liking it to him being asked if he "kissed a doorpost". Ignoring the simile, Carson asked Wilde on four separate occasions to explain his reason(s) for mentioning Grainger's "ugliness" and at that point Wilde suggested it was because Carson's "insolent questions" had "stung" him to the point that he had become "flippant" in his answers. Wilde also stated that he believed that Carson was deliberately insulting him even though Carson 
had stated only a few questions earlier that he had "to ask these questions". Rather than address Wilde's claim that he was deliberately goading him, Carson re-presented Wilde's "flippant" comment in his own words as a clarifying device. Wilde's response - "Oh, don't say what I wish to convey. I have given you my answer" - gives a sense of his consternation at this point, and his willingness to concede - "Oh, it was a flippant answer, yes: I will say it was certainly a flippant answer" - a sense of his (emotional and physical) weariness. That weariness had been occasioned by Carson's onslaught for nearly a day and a half. The good news, for Wilde, was that Carson brought his cross-examination to a close shortly afterwards. The bad news was that, as Carson started his opening speech shortly after, it became obvious that the defence had managed to locate several male prostitutes who were prepared to testify that they had had sex with Wilde, and that Carson would be questioning them. As explained in Section 2, Wilde accepted the advice of his counsel, and dropped his libel prosecution. Under the 1843 Libel Act, this meant that Wilde had to pay the expenses incurred by Queensberry, which left him bankrupt.

\section{Facework in a courtroom context: Some final thoughts}

Issues arising from this analysis give rise to two important questions, in my view. First, should we be talking about impoliteness in the courtroom (even when investigating the cross-examination phase)? Second, this paper demonstrates that our understanding of facework in a courtroom context can be enhanced via a consideration of reality paradigms (and their strategic manipulation); but are reality paradigms likely to be of importance for other facework studies?

Regarding the impoliteness issue, Carson was almost certainly hoping for such emotional responses from Wilde as those we see in Section 7. Hence his use of deliberate aggression, as a means of exacerbating, boosting or maximizing Wilde's obloquy (Bousfield 2008: 72). However, because Carson was doing what his job legitimately allowed him to do putting Wilde under intense pressure so that the "truth" emerged in spite of Wilde's best efforts to conceal it (Lakoff 1990: 90) - it's problematic to see Carson's actions as constituting impoliteness. The reason? He was not engaging in marked behaviour in facework terms (cf. Watts 2003), from a professional perspective at least (but see below). That said, as I argue throughout this paper, Carson's actions and hence any resultant "face-damage-as-by-product" were more planned and more anticipated than what I believe Goffman (1967: 14) had in mind when he initially constructed his incidental level of facework. Hence my call for an "indeterminate-as-to-speaker" intent zone to sit between Goffman's incidental 
and intentional levels as a means of capturing how lawyers use indirectness/ambiguity to their advantage in the courtroom and also as a means of accounting for the fact that a lawyer's aggression is not "impoliteness" providing they operate within the rules of the courtroom, even when that aggression results in actual face-damage for the target(s).

Researchers who adopt a relational perspective in regard to facework have been the most vociferous in attacking notions of systematic impoliteness, arguing rightly (in my view) that "impoliteness" which is systematic should be regarded as a norm for a given community of practice (or activity type) and, as such, as politic as opposed to salient behaviour. They also query whether the participants involved in activity types where conflictive talk plays an important role (i. e., is the norm) would consider impoliteness to have taken place (Mills 2005: 27). But herein lies a potential conundrum, at least in regard to the courtroom: when prioritizing the perceptions of the participants involved (i.e., engaging in im/politeness ${ }^{1}$ research as opposed to $\mathrm{im} /$ politeness $^{2}$ research), how should we account for views of lay participants like Wilde, who - rather than feeling as though their professional interlocutors have acted within the "expected norms" - feel that the professionals have exceeded appropriacy expectations (cf. Culpeper 2005)?; and what would happen if we prioritized the perspectives of the lay participants rather than the legal professionals, as I have done here? Would we then have to conclude that the courtroom is a site of impoliteness? Of course, one answer might be to provide analyses that acknowledge the (conflicting) perspectives of lay participants and legal professionals, and leave open the question of whether im/politeness can be deemed to have taken place in the final instance. That is to say, we might seek to forge a path of research where discussions do not have at their core questions of im/politeness, and instead discuss 'facework' in all its various guises (cf. Harris forthcoming 2011). This is especially important in regard to other phases of the courtroom process (i.e., pleading, opening/closing speeches, examination-inchief ....). And it's likely to be an issue for many other activity types and communities of practice.

The second issue, when seeking to understand facework in a courtroom context, is the importance of recognizing how lawyers use/manipulate representational frames and reality paradigms, often at the same time as exploiting the "indeterminate-as-to-speaker-intent" zone. In this particular case, it was so that Carson might emphasize Wilde's moral "deviance", without having to explicitly state that Wilde was a deviant. How did Carson achieve this? He gave Wilde, the consummate speaker, an opportunity to "play to the gallery" (Holland 2003: xxix) during his cross-examination; and, in playing to the gallery, Wilde demonstrated "a dangerous lack of caution" (McKenna 2003: 497), allowing Carson, in 
turn, to frame Wilde as someone whose reality paradigm - in regard to truth and homosexuality - was not only deviant but extremely dangerous to Victorian society. The importance of this? It helped to confirm that Queensberry's actions were "for the public benefit"; something which had to be proven legally for Queensberry to be found not guilty ${ }^{7}$.

Locher and Watts (2008) have already shown that interlocutors draw on context-specific expectation frames when negotiating face (their own and others') in a variety of activity types/communities of practice, and use those same frames when making decisions with regard to whether a behaviour is politic or salient (i.e., adheres to or exceeds participants' appropriacy expectations for that given activity/community of practice). Are "reality paradigms" equally useful beyond the courtroom? My claim would be that they will prove to be useful when investigating datasets representative of conflict in some way (systematic or otherwise) and/or an element of "performance". They should also prove useful when analyzing ideologically-loaded datasets. One could argue, of course, that all datasets are ideological: we just have more trouble uncovering the ideology or ideologies that our experiences or lifestyle have legitimated and habitualized. Yet, it is such "automatic and unanalytic" perceptions (Fowler 1986: 29-30) which - when brought into the light - will likely tell us most in regard to the way(s) in which reality paradigms influence facework.

\section{Acknowledgments}

My thanks to an anonymous reviewer for very helpful feedback.

\section{Bionote}

Dawn Archer is Reader in Corpus Linguistics at the University of Central Lancashire, UK. Her corpus linguistic work focuses on the development of tools to aid the 'mining' of historical data and/or the development of socio-pragmatic annotation schemes. Archer is also interested in pragmatics more generally. Much of her pragmatics-related work is courtroom focused: she is particularly fascinated by the development of (English) adversarial practices - hence her growing interest in facework and the courtroom. Her publications include Historical Sociopragmatics: Questions and Answers in the English Courtroom (1640-1760) and The Pragmatics Reader (edited with Peter Grundy).

E-mail: DEArcher@uclan.ac.uk 


\section{Notes}

1. There is some confusion over what was written on the card. Some suggest it contained the spelling error "somdomite", others that it stated "For Oscar Wilde ponce and sodomite". The latter would have been a more serious defamatory libel, (i) because of the negative meanings associated with ponce (i. e., a pimp who organized prostitutes or "an obvious, effeminate man, who might also be involved in prostitution": McKenna 2003: 462), and (ii) because "Queensbury would have had to prove that Oscar was an habitual associate of prostitutes", who "lived off their immoral earnings" and/or "procured boys to act as prostitutes" (2003: 462) if he were to justify the libel. This might help to explain Queensbury's insistence before the Magistrate (March $2^{\text {nd }}$ ) that the words he had written on the card were "posing as sodomite" (Holland 2003: 4).

2. Unless stated otherwise, I am using Holland's (2003) version of Regina vs. John Douglas as my dataset as it is the most complete version to date. Holland draws primarily on the longhand manuscript of the complete Queensberry trial, which was donated to the British Library in 2000, supplementing it with Millard's/Mason's (1912) Oscar Wilde: Three Times Tried (London: Ferrestone Press), Hyde's (1948) The Trials of Oscar Wilde (London: William Hodge), and various newspaper reports.

3. Holland suggests Clarke probably introduced the letter to defuse what might become a possible line of future attack by Carson, but it transpired that Carson hadn't known about the letter prior to Clarke mentioning it in his opening.

4. According to Goffman's (1967: 14) description, incidental facework is the "unplanned but anticipated by-product of action - action the offender performs in spite of its offensive consequences, although not out of spite" (my italics).

5. As McKenna (2003: 484) explains, "[b]y a quirk of the system for selecting jurors, nine of the twelve jurymen were from the neighbouring parishes of Clapton and Stoke Newington in north-east London". Moreover, "[i]t was, reported the Star, 'a common-looking jury', a stolid, solid jury of lower middle-class men brimful of Victorian values of morality, continence and respectability. They must have regarded Oscar as a bizarre creature far removed from their own world".

6. Although "You are a gentleman who understands a question perfectly" can operate as a compliment in some contexts, the juxtaposition of Carson's statement and his earlier request that Wilde be brief made Carson's insinuation here clear: that Wilde was being deliberately and unduly elusive.

7. In Victorian libel trials, the Jury had to address/confirm two issues, if they were to find a defendant innocent of all charges: that "the statement was true" and that the claims made therein had been "for the public benefit".

\section{References}

Archer, Dawn. 2002. "Can innocent people be guilty?". A sociopragmatic analysis of examination transcripts from the Salem witchcraft trials. Journal of Historical Pragmatics 3 (1). 1-30.

Archer, Dawn. 2008. Verbal aggression and impoliteness: Related or synonymous? In Derek Bousfield \& Miriam A. Locher (eds.), Impoliteness in language: Studies on its interplay with power in theory and practice (Language, Power and Social Process 21), 181-207. Berlin and New York: Mouton de Gruyter.

Archer, Dawn. Under review. Lawyers, facework and the adversarial courtroom. Submitted to the Journal of Pragmatics (March 2010). 
Bourdieu, Pierre. 1990. Language and symbolic power. Cambridge: Polity Press.

Bousfield, Derek. 2008. Impoliteness in interaction. Amsterdam \& Philadelphia: John Benjamins.

Culpeper, Jonathan. 2005. Impoliteness and entertainment in the television quiz show: The Weakest Link. Journal of Politeness Research 1 (1). 35-72.

Fowler, Roger. 1986. Linguistic criticism. Oxford: Oxford University Press.

Goffman, Erving. 1967. Interaction ritual: Essays on face-to-face behaviour. New York: Pantheon Books.

Grice, H. Paul. 1989. Studies in the way of words. Cambridge, MA: Harvard University Press.

Harris, Sandra. 1984. Questions as a mode of control in magistrates' courts. International Journal of the Sociology of Language 49. 5-27.

Harris, Sandra. Forthcoming 2011. The limits of politeness re-visited: Courtroom discourse as a case in point. In Linguistic Politeness Research Group, Discursive Approaches to Politeness. Berlin \& New York: Mouton de Gruyter.

Holland, Merlin. 2003. The real trial of Oscar Wilde. The first uncensored transcript of the trial of Oscar Wilde vs. John Douglas (Marquess of Queensberry), 1895. New York: Perennial, HarperCollins.

Ide, Nancy. 1989. Formal forms and discernment: Two neglected aspects of universals of linguistic politeness. Multilingua 8. 223-248.

Lakoff, Robin. 1989. The limits of politeness. Multilingua 8 (2/3). 101-129.

Leech, Geoffrey N. 1983. Principles of Pragmatics. London: Longman.

Locher, Miriam A. \& Richard J. Watts. 2008. Relational work and impoliteness: Negotiating norms of linguistic behaviour. In Derek Bousfield \& Miriam A. Locher (eds.), Impoliteness in language: Studies on its interplay with power in theory and practice (Language, Power and Social Process 21), 77-99. Berlin \& New York: Mouton de Gruyter.

McKenna, Neil. 2003. The secret life of Oscar Wilde. London: Arrow Books.

Mills, Sara. 2005. Gender and impoliteness. Journal of Politeness Research 1 (2). $263-280$.

OBP (Old Bailey Proceedings Online). March 1895. Trial of John Sholto Douglas, Marquis of Queensberry. Breaking peace: Libel (t18950325-336) www.oldbailey online.org (accessed 20 July 2010).

OBP (Old Bailey Proceedings Online). May 1895. Trial of Oscar Fingal O'Fflahartie Wills Wilde \& Alfred Waterhouse Somerset Taylor. Sexual offences: Sodomy (t18950520-425) www.oldbaileyonline.org (accessed 20 July 2010).

Penman, Robyn. 1990. Facework and politeness: Multiple goals in courtroom discourse. In Karen Tracy \& Nikolas Coupland (eds.), Multiple goals in discourse, 15-38. Clevedon and Philadelphia: Multilingual Matters Ltd.

PRO (Public Record Office) REF. CRIME 4/1118. Plea of justification filed by the defendant in Regina (Wilde) vs. Queensberry. Central Criminal Court: Indictments, National Archives, Kew.

Searle, John R. 1975. Indirect speech acts. In Peter Cole \& Jerry L. Morgan (eds.), Syntax and semantics: Speech acts, vol. 3, 59-82. New York: Academic Press.

Spencer-Oatey, Helen 2002. Managing rapport in talk: Using rapport sensitive incidents to explore the motivational concerns underlying the management of relations. Journal of Pragmatics 34. 529-545.

Sperber, Dan \& Deidre Wilson 1986. Relevance: Communication and cognition, Oxford: Blackwell.

Thomas, Jenny 1995. Meaning in interaction. London \& New York: Longman.

Watts, Richard J. 2003. Politeness. Cambridge: Cambridge University Press. 